\title{
Determinants of Cow Milk Commercialization in Yabello District, Borana Zone of Oromia National Regional State, Ethiopia
}

\author{
Sinbone Tefera Walkaba*1 Mengistu Ketama (PHD) $^{2} \quad$ Kumilachew Alamerie (Msc) ${ }^{3}$ \\ 1.Oromia Agricultural Research Institute (OARI), Holeta Bee Research Center P. O. Box 22, Holeta, Ethiopia \\ 2.Professor in Department of Agricultural Economics, Haramaya University, P. O. Box 138 Haramaya \\ University Dire Dawa, Ethiopia \\ 3.Associate Professor in Department Agricultural Economics, Haramaya University, P. O. Box 138 Haramaya \\ University, Dire Dawa, Ethiopia
}

\begin{abstract}
Milk is an important dairy product socially and economically in pastoral area of Ethiopia generally and Yabello district particularly. It is a source of food and cash income for the majority of milk producers. This study was aimed at analyzing cow milk market participation and determinants of cow milk commercialization. Data were collected from 154 randomly selected producers in the district through a structured questionnaire. Both descriptive statistics and econometric models were used to analyze the data. The double hurdle model was used for analyzing cow milk market participation (first hurdle) and determinants of cow milk commercialization (the second hurdle). In first hurdle, the result of Probit Regression Model revealed that cow owned (TLU), cooperatives membership, production experience, market place, availability of labor force (adult equivalent) and age of the household head played a significant role in cow milk market participation. In the second hurdle, the result of Truncated Regression Model revealed that cows owned (TLU), milk production experience (year), market distance and age of the household head were found to significantly influence the cow milk commercialization in the study areas. Therefore, focuses are needed to support households for dairy commercialization in the study area. Especially, focus should be given to the establishment of a market place for milk and dairy product, supporting cooperative, selection of local breed, which determine the cow milk commercialization in the study area.
\end{abstract}

Keywords: dairy commercialization, Yabello, Smallholder, Market Participation, Tobit, probit

DOI: $10.7176 / \mathrm{JMCR} / 78-03$

Publication date: April $30^{\text {th }} 2021$

\section{INTRODUCTION}

Agriculture sector remains a key for the national economy of Ethiopia. It accounts for $36.7 \%$ of overall GDP, $70 \%$ of foreign exchange earnings and also the sector provides employment opportunity for $72.7 \%$ of the population and is a means of generating livelihood for about $83 \%$ of the rural population (ATA, 2017). The Ethiopian government, in its two-consecutive five years Growth and Transformation Plan (GTP-I and GTP-II), has given much emphasis on agricultural commercialization, among which the second pillar aims to achieve growth and thereby improve people's livelihoods and reduce poverty(MoFED, 2015).

Commercialization of the smallholder farmers has been seen by the government as the major source of agricultural growth in Ethiopia. The government of Ethiopia implemented agricultural commercialization clusters with the primary goal of commercialization of smallholders' agriculture and agro-industrial development, contributing to a strategic access point for private sector engagement (Pauw, 2017).

Livestock production as one component of the agriculture industry plays an important role in the economic and social development of Ethiopia at national and household level. The countries holds large potential for dairy development due to its large livestock population, the favorable climate for improved, high-yielding animal breeds, emerging market opportunity, improved policy environment for involvement of private sectors, and the relatively disease-free environment for livestock (Matawork, 2016).

In the economy of the country, livestock is the main household asset and a key productive resource for pastoralist communities especially living in the border areas of Ethiopia. Thus, the pastoral area owns about 40 percent of the country's total livestock population. The livelihood of pastoral communities of the Oromia lowlands mainly Borana is based on livestock and livestock products. Borena zone is one of the pastoralist zones depending on livestock rearing, which have livestock population of 1,056,040 cattle, 868,571 goats, 573,369 sheep, 1096 horses, 3149 mules, 81,023 donkeys, 51,607 camels'490,717 poultry and 64,699 bee-keeping (CSA, 2017).

Milk is one of the most important livestock products and the main diet for pastoralists in the Borena pastoral communities. It is also used as the main income sources for the women pastoralists (CARE, 2009). In Borana pastoral communities, the total overall average milk produced is estimated to be 129,029 tons. Daily it is 353,504 liters, of these milk constitutes 69,864,58,016, and 1,149 tons from cows, and camel and shoat milk, respectively. In terms of the market share cow, camel and shoat milk constitute $59.4 \%, 39.4 \%$ and $31.2 \%$ respectively. However, Borana pastoralists were not economically benefited to the extent it should be. Similarly, both the productivity and 
price variability is higher in pastoral areas whereas the product may vary due to unpredictable rains and other natural hazards (Yacob and Catley, 2010). Therefore, identifying the factors that determine cow milk market participation and commercialization is very important for both research and development interventions to improve and diversify the income of households.

\subsection{Objectives of the Study}

The major objective of this study is to identify the determinants of cow milk commercialization in Yabello District of Borana Zone, Ethiopia.

The specific objectives of the study are:

1. To identify the factors that determine cow milk market participation in the study

2. To identify the determinants of cow milk commercialization in the study area

\section{RESEARCH METHODOLOGY}

\subsection{Description of the Study Area}

The study was conducted in Yabello district of the Borana zone of the Oromia Regional State. The Yabello districts is one of the 13th districts of Borena zone located at Central of the Zone and also Zonal capital which is located at $570 \mathrm{~km}$ from Addis Ababa to Southern at main road of Addis Abeba to Moyale. According to the information obtained from Woreda Administration and Communication Office the total population of the district were 63,648 out of which 36,382 were men and 27,266 were female. The total households of rural kebeles of the district were 10,048 out of which 7880 were male and 2168 were female. The estimated area of the district is 555,000 square kilometers with an estimated population density of 14.9 people per square kilometer, which is less than the zone average that is 21.1 people per square kilometer.

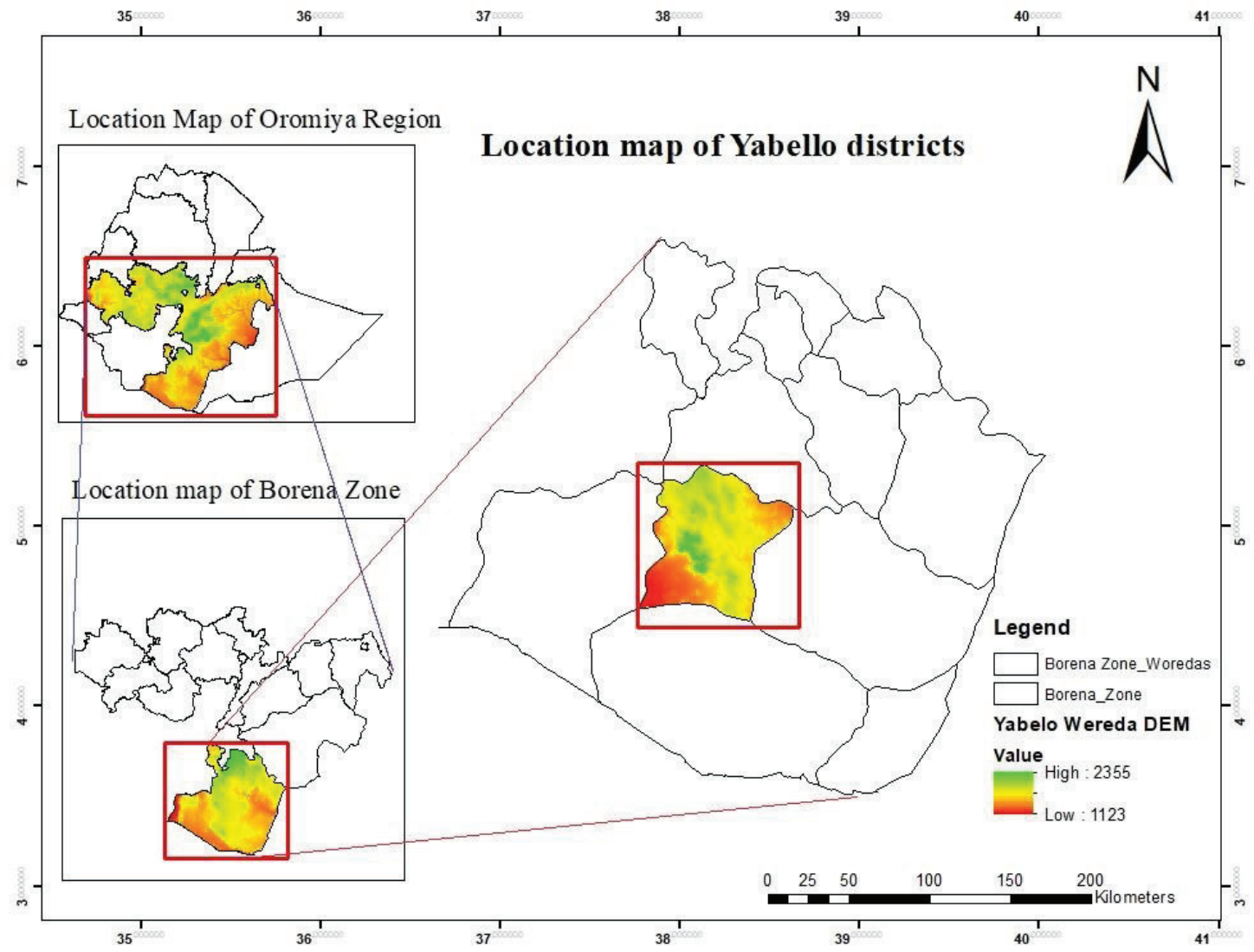

Figure1. Location of the study area

\subsection{Data Type, Sources and Methods of Data Collection}

Both quantitative and qualitative data were collected from of primary and secondary sources. Primary data were collected from randomly selected milk producers and checklist was used to generate data through group discussion and key informants. Personal observation and informal discussions were made to elicit information to support the data obtained from the producers. Besides primary data, secondary data were reviewed from various sources such as documents from the district office of livestock and pastoral development and empirical findings related to the topic of interest. Structured and semi-structured interview schedules and checklists were developed and pre-tested 
to collect data from producers. Trained enumerators, who are familiar with the local culture and language, were used to conduct the survey.

\subsection{Sampling Procedures and Sample Size Determination}

Purposive and two stages random sampling procedure was used for the selection of sample household heads. Yabello district was selected purposively since it is the potential .In the first stage, four cow milk-producing kebeles; namely; Haro bake,Yubdo, Dadim, and Dikale were selected randomly. In the second stage, from the total of 2801 households in the selected four kebeles, 154 sample household heads were selected randomly, using probability proportionate to the size of cow milk producer's households in the kebeles. to determine the required sample size, this study used a simplified formula developed by Yamane (1967) was used to minimize the availability of error and bias during sample determination. Therefore, the required sample size at $95 \%$ confidence level with a degree of variability of $5 \%$ was used to obtain a sample size required to represent the true population. The total sample size $(\mathrm{n}=154)$ was determined following a simplified formula provided by Yamane (1967).

$n=N / 1+N(e)^{2}$

Where: $\mathrm{n}=$ sample size, $\mathrm{N}=$ population size (sampling frame) and $\mathrm{e}=$ level of precision.

Table 1: Sample distribution of households of cow milk producer in selected kebeles

\begin{tabular}{lll}
\hline Name of kebele & $\begin{array}{l}\text { Total number of Households (cow } \\
\text { milk producers) }\end{array}$ & Number of sampled households \\
\hline Yubdo & 657 & 36 \\
Haro bakes & 413 & 23 \\
Dikaale & 1195 & 66 \\
Daddim & 536 & 29 \\
Total & 2801 & 154 \\
\hline
\end{tabular}

Source: Yabello District Pastoral Office, (2019) and own computation result

\subsection{Methods of Data Analysis}

Both descriptive statistics and econometric model were employed for analyzing the data collected from smallholder cow milk producers.

\subsubsection{Descriptive statistical analysis}

Descriptive statistical analysis method such as mean, proportions, percentages, and standard deviations were used.

\subsection{Econometric Analysis}

In this study, the cow milk market participation and commercialization index are the dependent variables. the double hurdle model was selected and used for the sake of analyzing cow milk market participation (first hurdle) and determinants of cow milk commercialization (the second hurdle) of cow milk producer. The first hurdle model, which is probit is used in estimating the factors determining the probability of participation in cow milk market. Truncated regression as one part of Double hurdle model has been used in estimating the determinants of cow milk commercialization.

Participation decision equation is specified as follows:

$Y_{i 1^{*}}=x_{1} \beta_{1}+\varepsilon_{i 1}, \varepsilon_{i 1} \sim N\left(0, \delta_{12}\right)$

$Y_{i 1}=\left\{\begin{array}{l}1, \text { if } Y_{i 1^{*}}>0 \\ 0, \text { if } Y_{i 1^{*}} \leq 0\end{array}\right.$

Cow milk commercialization equation is specified as:

$Y_{i 2^{*}}=X_{2} \beta_{2}+\varepsilon_{i 2}, \varepsilon_{i 2} \sim N\left(0, \delta_{2^{2}}\right)$

$Y_{i 2}=\left\{\begin{array}{r}X_{2 \beta_{2}+\varepsilon_{i 2},} \text { if } Y_{i 1=1} \text { and } Y_{i 2 *}>0 \\ 0, \text { if } Y_{i 2^{*}} \leq 0\end{array}\right.$

Where $Y_{i 1^{*}}$ is unobserved (latent) variable for the cow milk market participation decision

$Y_{i 1}$ is the observed discrete decision of the producer whether he/she has participated or not in cow milk market, the subscript $i$ refers to the $\mathrm{i}^{\text {th }}$ household, the subscripts 1 and 2 refer to the variable and parameters related to the participation equation and the level of participation, respectively.

$X_{l}$ 's are the index of explanatory variables determining the participation decision of the producer in cow milk market,

$X_{2}$ 's are the index of explanatory variables determining the determinants of cow milk commercialization.

$\beta_{1}$ refers to the index of parameters related to explanatory variables determining participation decision of the 
producer,

$\beta_{2}$ refers to the index of parameters related to explanatory variables that determining the determinants of cow milk commercialization by producers,

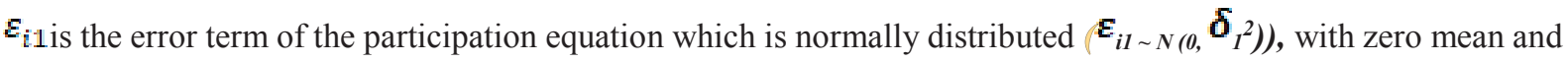
constant variance,

$\varepsilon_{i 2}$ is the error term equation which is normally distributed $\left(\varepsilon_{i 2 \sim} N\left(0, \delta_{2}{ }^{2}\right)\right.$ with zero mean and constant variance, $Y_{i 2}$ Unobserved (latent) variable for the participation of producer in cow milk market,

$Y_{i 2}$ is the observed actual number of the cow milk market

Analysis of the Marginal Effects of Participation Decision

The marginal effects that are determined from the estimation of probit part of double hurdle model in this particular study interest could be determined by using the formula of partial derivations/ partial effects.

The marginal effect, the effect of a unit change or discrete change in explanatory variables on the probability of participating milk market can be given as follows.

$\frac{\partial P\left(Y_{\left.i 1=1 / X_{i}\right)}\right.}{\partial X_{j}}=\beta_{j} \varnothing(X \beta)$

Where $\beta_{j}$ is the coefficient on $\mathrm{x}_{\mathrm{j}}$ and $\emptyset(\mathrm{x} \beta)$ is the standard normal probability density function which would be

evaluated at $\left(\beta_{0}+\beta_{1} X_{1}+\beta_{2} X_{2+\cdots}\right)$.

For the continuous explanatory variables, these marginal effects are used to calculate elasticity at the sample means because the slope of the dependent variable is not constant at different per unit change of the variables. For the discrete or categorical variables, the marginal effects are used to calculate percentage changes in the dependent variable when the variable shifts from zero to one, ceteris paribus.

\subsection{Definition of Variables and Working Hypotheses}

To identify the factors affecting cow milk market participation decision and the determinants of cow milk commercialization of producers, the definition and hypothesis as to how these factors are related to the dependent variables are required. Accordingly, the dependent and independent variables are defined and hypothesized as follow.

\section{Dependent variables}

Milk market participation (SALE): It is a dummy dependent variable that represents the probability of milk market participation of households. The variable takes the value one for a household who participates in milk market whereas it takes the value of zero for the household who does not participate in the milk market. This is regressed in the probit model framework (The first hurdle).

Commercialization index (HCI): It is a limited dependent variable, which is measured as the ratio of the gross value of milk sales to a gross value of milk produced by the household in 2018/19 production year and it is expressed in percentage. This is regressed in the truncated model framework (The second hurdle).

Table 2: Summary and hypothesis of independent variables for market participation and commercialization of cow milk

\begin{tabular}{|l|l|l|l|}
\hline Variable & Type & Measurement & $\begin{array}{l}\text { Expected } \\
\text { sign }\end{array}$ \\
\hline Age & Continuous & Age of household & + \\
\hline Sex & Dummy & 1 if the household head is male and 0 otherwise & - \\
\hline $\begin{array}{l}\text { Milk production } \\
\text { experience }\end{array}$ & Continuous & Number of years of involving in milk production & + \\
\hline Family size & Continuous & Number of family members in the household & - \\
\hline Distance & Continuous & Distance from town/market in kilometers & - \\
\hline Market place & & 1 if there is shade for milk in the market area or 0 other & + \\
\hline $\begin{array}{l}\text { Nonfarm/off farm } \\
\text { income }\end{array}$ & Continuous & $\begin{array}{l}\text { monetary value(ETB) and shows the amount of income } \\
\text { obtained from other activities }\end{array}$ & - \\
\hline Extension contact & Dummy & 1 if the person is have extension contact or 0 otherwise & + \\
\hline Cooperatives & Dummy & 1 if the person is a member of cooperatives or 0 otherwise & + \\
\hline Education & Continuous & the household head Access to education & + \\
\hline $\begin{array}{l}\text { Number of cows } \\
\text { Continuous }\end{array}$ & $\begin{array}{l}\text { number of milking cows owned by a household in Tropical } \\
\text { Livestock Unit (TLU) }\end{array}$ & + \\
\hline Land & Continuous & The size of the household land holding for grazing & + \\
\hline
\end{tabular}




\section{RESULTS AND DISCUSSION}

\subsubsection{Descriptive statistical analysis}

Among 154 sample respondents, 129 of them were cow milk market participants and the rest 25 respondents were non-participants. Group comparison of the market participants and non-participants was figured out using $\chi^{2}$-test for dummy variables and t-test for continuous variables, as it is presented in Tables 3 and Table 4 respectively..

As indicated in Table 3, regarding cooperative memberships out of total sample respondents, 27(16.23\%) were cooperative members and the remaining $127(83.77 \%)$ were not organized under cooperatives. Concerning to milk market places, from total sample respondents $21(13.6 \%)$ households have appropriate milk market place whereas $133(86.4 \%)$ have no milk market place among market participants. In terms of extension services, out of the total sample respondents, 14 (7.8\%) have to access to extension service while $142(92.2 \%)$ have not.

Table 3: Test statistics of market participant and non-participant (chi ${ }^{2} /$ Fisher's exact test) $^{2}$

\begin{tabular}{|c|c|c|c|c|c|c|c|}
\hline \multirow{2}{*}{ Variables } & \multicolumn{2}{|c|}{ Participants } & \multicolumn{2}{|c|}{ Non-participants } & \multicolumn{2}{|c|}{ Total } & \multirow{2}{*}{$\chi^{2}$-value } \\
\hline & $\mathrm{N}$ & $\%$ & $\mathrm{~N}$ & $\%$ & $\mathrm{~N}$ & $\%$ & \\
\hline \multicolumn{8}{|l|}{ Cooperative membership } \\
\hline Involving & 26 & 20.2 & 1 & 4.00 & 27 & 16.23 & \multirow{2}{*}{$3.7801^{*}$} \\
\hline Excepted & 103 & 79.8 & 24 & 96.0 & 127 & 83.77 & \\
\hline \multicolumn{8}{|c|}{ Availability of Milk Market Place } \\
\hline Exist & 8 & 38.10 & 13 & 61.9 & 21 & 13.64 & \multirow{2}{*}{$37.2976^{* * *}$} \\
\hline Missed & 121 & 90.98 & 12 & 9.02 & 133 & 86.36 & \\
\hline \multicolumn{8}{|c|}{ Access to Milk Extension services } \\
\hline $\begin{array}{l}\text { Access } \\
\text { Not access }\end{array}$ & $\begin{array}{r}16 \\
113\end{array}$ & $\begin{array}{r}100.00 \\
81.88\end{array}$ & $\begin{array}{r}0 \\
25\end{array}$ & $\begin{array}{r}0.00 \\
18.12\end{array}$ & $\begin{array}{r}12 \\
142\end{array}$ & $\begin{array}{r}7.79 \\
92.21\end{array}$ & $3.4603^{*}$ \\
\hline
\end{tabular}

Source: Own survey result, 2019

$* * *, * *$ and $*$ implies statistically significance at 1,5 , and $10 \%$ levels, respectively.

The mean of dairy milk selling experience of milk market participants and nonparticipants were 4.9 and 0 respectively. With regard to distance to the nearest market, the producers sold their milk products walking 6.5 hour on average. In the study area, mixed crop and livestock farming system were practiced which is dominated by livestock productions. Livestock resources are useful in the livelihoods of smallholder's producers.

Table 4: Summary statistics of variable by market participation status (continuous variable) mean and standard error

\begin{tabular}{|c|c|c|c|c|}
\hline Variables & $\begin{array}{l}\text { Participant } \\
(\mathrm{n}=129)\end{array}$ & $\begin{array}{l}\text { Non-participant } \\
(\mathrm{n}=25)\end{array}$ & $\begin{array}{c}\text { Total } \\
(\mathrm{n}=154)\end{array}$ & t-value \\
\hline Milk selling Experience (Years) & $4.96 \pm 0.36$ & 0 & $4.15 \pm 0.34$ & $5.98^{* * *}$ \\
\hline Total No of Livestock (TLU) & $11.43 \pm 7.29$ & $6.47 \pm 2.66$ & $10.63 \pm 6.99$ & $3.35^{* * *}$ \\
\hline No cow owned (TLU) & $3.07 \pm 3.426$ & $1.8 \pm 1.756$ & $2.863 \pm 3.244$ & $1.80^{*}$ \\
\hline Distance to the nearest market (Hr.) & $6.95 \pm 0.70$ & $4.20 \pm 1.57$ & $6.50 \pm 0.64$ & $1.64^{*}$ \\
\hline
\end{tabular}

Source: Own survey result, 2019

$* * *, * *$ and $*$ implies statistically significance at 1,5 , and $10 \%$ levels, respectively.

\subsection{Econometric Analysis}

Prior to the econometric analysis, essential tests that verify the model to employ for the analysis were undertaken on hypothesized variables. The double hurdle model was applied to analyze determinants of cow milk commercialization and market participation. This double hurdle model involves two-step estimation procedure. In first stage, probit model was used to explore factors governing market participation decision for a given reference period which is referred to as commercialization decision in this study.

\subsubsection{Factors determining cow milk market participation}

The result of probit model estimation that whether the household's decision to participate in cow milk market or not (Table 5). The probit model has been estimated by the maximum likelihood method. Marginal effect was used as a useful measure to explain the result as coefficients of the probit model are difficult to interpret since they measure the change in the unobservable $\mathrm{y}^{*}$ associated with a change in one of the explanatory variables (that is, not partial effects). The overall model is significant at 0.000 levels as indicated by log likelihood value of-43.108. Moreover, based on pseudo $\mathrm{R}^{2}$ of 0.369 the model appears to have good fit to the data (Table 5).

Cow ownership: As expected the variable has positive and significant effect at $1 \%$ on households' cow milk market participation. The positive and significant relationship between the two variables indicated that as the number of milking cows owned increased by a TLU, the milk production per household increases, turn increasing the percentage share of cow milk sold per day per households. The marginal effect of the variable confirm that a unit increase in milking cow by TLU leads the probability of participating in milk market to rise by $3.2 \%$ (Table 5). The result is in line with Berhanu et al. (2014). 
Cooperatives membership: As expected the variable has positive and significant effect at $5 \%$ on households' cow milk market participation. The positive and significant relationship between the two variables show that the households who are cooperative member had access to sell their milk at a cooperative place that minimizes the time they devote to sell milk at the market place and transportation costs and this motivates the households to participate in milk markets. The marginal effect of the variable confirms that as the household member of cooperatives the probability of participating in milk market to rise by $7.1 \%$. The result is in line with Geremew, 2016.

Milk production experience: As hypothesized milk production experience of the household was found to have positive and significant effect on cow milk market participation at $1 \%$. This indicates that household heads who have more milk production experience are expected to be more knowledgeable, this improves the productivity and quantity of milk sold turn leading to an increase in the probability of cow milk market participation The marginal effect of the variable confirm that as the year of milk production of the household increased, market participation of cow milk increases by $1.3 \%$ (Table 7). The result is contrary with Berhanu et al. (2014).

Table 5: Estimated cow milk market participation model part of double hurdle (probit part)

\begin{tabular}{|c|c|c|c|c|}
\hline Independent Variables & Coefficients & Robust Std. Err. & $\mathbf{P}>|\mathbf{z}|$ & $\begin{array}{l}\text { Marginal Effects } \\
(\text { dy/dx) }\end{array}$ \\
\hline Education level of the household & -0.484 & 0.388 & 0.212 & -0.065 \\
\hline Cow ownership(TLU ) & 0.308 & 0.113 & $0.007 * * *$ & 0.032 \\
\hline Cooperatives membership & 1.150 & 0.559 & $0.040 * *$ & 0.071 \\
\hline Milk production experience & 0.126 & 0.051 & $0.013 * * *$ & 0.013 \\
\hline Extensions service & 0.694 & 0.489 & 0.156 & 0.047 \\
\hline Land holding size & 0.016 & 0.071 & 0.820 & 0.002 \\
\hline Market distance & -0.002 & 0.002 & 0.237 & 0.000 \\
\hline Access to market information & -0.711 & 0.450 & 0.114 & -0.049 \\
\hline Market place & 1.979 & 0.401 & $0.000 * * *$ & 0.489 \\
\hline Household size (Adult Equivalent) & -0.117 & 0.067 & $0.081^{*}$ & -0.012 \\
\hline Age of the head & -0.151 & 0.055 & $0.006 * * *$ & -0.016 \\
\hline Sex of household & -0.640 & 0.415 & 0.123 & -0.048 \\
\hline Access to credit service & -0.640 & 0.402 & 0.442 & -0.037 \\
\hline Income from off farm (ETB) & 0.000 & 0.000 & 0.374 & 0.000 \\
\hline Constant & 6.202 & 1.414 & $0.000 * * *$ & \\
\hline $\begin{array}{l}\text { Number of Obs. }=154 \\
\text { Wald chi2 }(14)=55.82 \\
\text { Prob }>\text { chi }^{2}=0.00 \\
\text { Pseudo } \mathrm{R}^{2}=0.369 \\
\text { Log likelihood }=-43.108\end{array}$ & & & & $\begin{array}{l}\mathrm{y}=\operatorname{Pr}(\mathrm{SALE}) \text { (predict) } \\
=0.95\end{array}$ \\
\hline
\end{tabular}

Source: Own computation result, 2019

Note: Symbols $* * *, * *$ and $*$ indicates significant at $1 \%, 5 \%$ and $10 \%$ levels, respectively.

Market place (MKTPC): Market place was found to positively and significantly contribute at $1 \%$ on the cow milk market participation. This indicated that appropriate and permanent market place to sell their milk product helps households to participate in the market that could increase the probability of cow milk market participation. The marginal effect showed that getting access to suitable market place by milk sellers will increase the probability of cow milk market participation by 48.9\% (Table 7). The result coincides with (CARE, 2009).

Household family size: As contrary to hypothesize the variable is found to negatively and significantly affect participation in cow milk market at $10 \%$. This indicates that the household with small family size had higher marketable milk surplus than households with larger family size and it indirectly affect the cow milk market participation. The negative impact of household size indicated that the higher the number of household members, the more they will consume their production. In other way, an increase in family size may also increase the number of dependent family members which would in turn increase the number of mouths to be fed and disproportionate volume of production and hence contribute to a decrease in the level of market participation. The marginal effect of the variable confirms that as member of household added to the family, the market participation of cow milk decreases by $1.2 \%$ (Table 7).The results inconsistent with the findings of Aman Tufa et al. (2014) and agree with (Koskeiet al., 2013)

Age of the house head: The result is contrary to prior expectation. The variable had negatively and significantly influenced households' participation in cow milk market at $10 \%$. This indicate that old aged household heads are more probable to minimize their livestock number due to their inability to feed them by cut and carry system as well as taking them to far remote grazing areas. Also they traditionally perceive milk to be used only for house consumption. The marginal effect indicated that as the age of the household head increases by 
one year, the probability of cow milk participation decreases by $1.6 \%$ (Table 7). This result agreed with the results of Woldemichael (2008) and Berhanu et al (2014), Cunningham et al. (2008) and Mahelet (2007) shows that age of the head negatively and significantly affects the degree of market participation.

\subsubsection{Determinants of commercialization of cow milk producer}

The factors that determine commercialization of cow milk producers was analyzed using truncated regression model.

The Truncated regression model estimated results showed that the likelihood function of commercialization index was significant at 1\% level indicating a strong explanatory power of independent variables to explain level commercialization of cow milk producers. The model result indicated that, out of explanatory variables used in the model; cow owned (TLU), cow milk production experience (year), market distance and age of household were found to significantly influencing the commercialization of milk producers in the study areas (Table 8).

Cow owned: Number of cows owned measured in TLU was found positively and significantly contribute to the level of cow milk commercialization at $1 \%$ significance level. This indicated that, as the number of milking cows owned increased by a TLU, the milk production per household increases. As a result the percentage share of milk sold per day per household's increase in turn increasing the probability of cow milk commercialization. The positive coefficient of livestock possession implies that an increase in cow possession by one TLU would increase the value of cow milk outputs of the household sold by about ETB 393.2. The result is in line with the finding of Getaneh (2005).

Milk production experience: As hypothesized milk production experience of the household head was found to have positive and significant effect on the level of cow milk commercialization at $1 \%$ significance level. The positive and significant relationship between two variable indicate that, the household heads who have longer milk production experience are expected to be more knowledgeable, this improves the productivity and quantity of milk sold this in turn could be increases the probability of cow milk commercialization. On average, more experience household earns about ETB 421.36 more as compared to less experience household head from sales of cow milk. This result in line with: (Edward et al., 2012) and (Staal et al., 2006)

Market distance: as expected distance to the nearest market was found negatively and statistically significant influence on level of cow milk commercialization at 5\% level. The shorter the time taken to reach the nearest market would result to a greater degree of commercialization of cow milk. Distance to market was negatively affecting the value of milk sold possibly because of the increased transaction costs associated with marketing of the products. This implies that the location of producer in respect of potential markets is an important factor in encouraging producers to increase their sales. The shorter the time taken to reach the nearest market would result to a greater degree of commercialization of cow milk. This result is in conformity with the findings of Berhanu and Moti (2010), which found that being closer to market, enhance commercialization of cow milk

Age of the head: As opposite to expectation, age of the household head had negative and significant impacts on the level of cow milk commercialization at 1\% significance level. This indicates that the young aged household heads use more input for dairy cows and have more milk participation that could increase the probability of cow milk commercialization. This finding was in agreement with the work of scholars such Tshiunza et al., (2001) and Berhanu et al., (2014) and disagrees with.

Table 6:Estimation of truncated part of double hurdle

\begin{tabular}{|l|l|l|l|}
\hline Independent Variables & Coefficients & RobustStd. Err. & $\mathbf{P}>|\mathbf{z}|$ \\
\hline Education level of the household & -134.942 & 2244.97 & 0.821 \\
\hline Cow ownership(TLU ) & $393.216^{* * *}$ & 182.066 & 0.006 \\
\hline Cooperatives membership & -2132.069 & 2254.118 & 0.295 \\
\hline Milk Production Experience & $421.36^{* * *}$ & 154.29 & 0.000 \\
\hline Extensions service & 1421.82 & 2263.06 & 0.371 \\
\hline Land holding size & -872.0337 & 505.9314 & 0.125 \\
\hline Market distance & $-9.210989^{* *}$ & 7.700695 & 0.036 \\
\hline Access to market information & -3552.424 & 1964.394 & 0.322 \\
\hline Market place & 2268.289 & 2770.278 & 0.207 \\
\hline Household size (Adult Equivalent) & 187.2218 & 122.4358 & 0.928 \\
\hline Age of the head & $-346.7945^{* * *}$ & 147.2641 & 0.000 \\
\hline Sex of household & 4406.946 & 2355.002 & 0.402 \\
\hline Access to credit service & 254.833 & 1789.523 & 0.295 \\
\hline Income from off farm (ETB) & 0.1509219 & 0.10249 & 0.759 \\
\hline Constant & $6055.507 * * *$ & 4702.395 & 0.000 \\
\hline Sigma & 5465.386 & 701.0462 & 0.000 \\
\hline
\end{tabular}

Source: Own computation result, 2019

Note: Symbols $* * *, * *$ and $*$ indicates significant at $1 \%, 5 \%$ and $10 \%$ levels, respectively. 


\section{CONCLUSION AND RECOMMENDATIONS}

The study aimed at analyzing cow milk commercialization in Yabello district of Oromia National Regional, State Ethiopia. The specific objectives of this study were to analyze the cow milk market participation and the determinants of cow milk commercialization. the Primary data were collected from randomly selected 154 milk producer households in four kebeles. Descriptive statistics and econometric models were used to analyze the collected data. Double hurdle model was employed to identify the factors determining commercialization. Double hurdle model involves two-step estimation procedure. In first stage, probit model was used to explore factors governing market participation decision and the truncated regression to analyze determinant of cow milk commercialization.

The result of probit estimation shows that the likelihood of household participation in cow milk market were influenced by owned (TLU), Cooperatives membership, production experience, market place, availability of labor force (Adult equivalent) and age of the household head. The Truncated regression model results shows that cow owned (TLU), cow milk production experience (year), market distance and age of household were found to significantly influencing the commercialization of milk producers in the study areas.

From the findings of this study the following relevant recommendations are forwarded in order to formulate appropriate intervention in this area. The recommendations are the following: Number of cows owned has positive and significant impact on cow milk market participation and commercialization. So, increasing the herd size with good milk producing cows should be emphasized to benefit producers. Thus to increase cow milk commercialization; there needs to be a crucial intervention by concerned development actors and partners for feed and water problem; in order to enable a stable feed and water supply throughout the year.

Cooperative member has positive and significant impact on cow milk market participation. The variables show that the households who are cooperative member had access to sell their milk at a cooperative place that minimizes the time they devote to sell milk at the market place and transportation costs and this motivates the households to participate in milk market. Therefore, the concerned body supports cooperative members through financing and training in order to increase the commercialization of cow milk producer.

More experienced households are better in cow milk market participation and commercialization. Provision of training to the pastoral communities is imperative so as to improve their knowledge and skills on the management of dairy animals. Thus, should be able to increase the awareness of households though experience sharing events in order to increase cow milk commercialization.

An increase in household size was found to have negative and significant influence on cow milk market participation. This is because households with large household member consume more proportion of cow milk produce and reduce the amount that is going to be sold. Since production resources are limited intervention on family planning based on interest of pastoral, by showing its negative impact is important in the study areas.

Market distance the shorter the time taken to reach the nearest market would result to a greater degree of commercialization of cow milk. as a result, improving rural infrastructure in developing market infrastructure in the form of establishing produce collection points across rural areas would assist poor producer for faster delivery

The results of the study showed that age of household head is negatively affecting cow milk participation and the level cow milk commercialization. This means old aged household heads are more probable to minimize their livestock number due to different reasons. Hence, supporting older aged households through training to participate in cow milk marketing is important for cow milk commercialization. Therefore there is a need for investment in areas such as transport systems, improvement of market place and setting up modern market infrastructure.

\section{REFERENCES}

ATA (Agricultural Transformation Agency).2017. Agricultural Transformation Agenda, Annual Report of 201617. Addis Ababa, Ethiopia.

Aman Tufa,Adam Bekele and Lemma Zemedu, 2014. Determinants of smallholder commercialization of horticultural crops in Gemechis District, West Hararghe Zone, Ethiopia. African Journal of Agricultural Research, 9(3):310-319.

Berhanu Gebremedhin and Moti Jaleta.2010. Commercialization of smallholders: Does market orientation translate into market participation? Improving productivity and market success of Ethiopian farmers project (IPMS), (ILRI).Working Paper No. 22. Addis Abeba, Ethiopia.

Berhanu Kuma, Derek B., KindieGetnet and Belay Kassa. 2014.Factors Affecting Milk Market Participation and Volume of Supply in Ethiopia.Asian Journal of Rural Development, 4: 1-15.

CARE-Ethiopia (2009) Value Chain Analysis of Milk and Milk products in Borena Pastoralist Area. Regional Resilience Enhancement against Drought Project, Yonas Business Promotion and Consultancy P LC, Addis Ababa, Ethiopia.

CSA (Central Statistical Agency). 2017.Federal Democratic Republic of Ethiopia Agricultural Sample Survey 2016/2017 (2009 E.C): Report on livestock and livestock characteristics, volume-II. Addis Ababa, Ethiopia.

Edward M., Ramatu M. Al-Hassan and John K. M. Kuwornu, 2012. Commercialization of smallholder agriculture 
in Ghana:A Tobit regressionanalysis.African Journal of Agricultural Research.

Efa Gobena, Degye Goshu, Tinsae Demisie and Tadesse Kenea. 2016. Determinants of market participation and intensity of marketed surplus of Tef producers in Bacho and Dawo districts of Oromia, Ethiopia Journal of Agricultural Economics and Development.

Geremew Kefyalew. 2016. Analysis of Smallholder Farmer's Participation in Production and Marketing of Export Potential Crops: The Case of Sesame in Diga District, Oromia Regional State, Msc. Thesis, Addis Abeba University, Ethiopia

Gizachew Getaneh, 2005 .Dairy marketing pattern and efficiency the case of Ada liben District, Eastern Oromia,Msc.thesis, Haramaya University,Ethiopia.

Koskei, J.K., Langat, E.C. and Oyugi, M.A. 2013. Determinants of Agricultural Information Access by Small Holder Tea Farmers in Bureti District, Kenya.Asian Journal of Agricultural Sciences 5(5): 102-107.

MaheletGetachew. 2007. Factors affecting commercialization of smallholder farmers in Ethiopia: the case of North Omo Zone, SNNP region. Paper Presented at the $5^{\text {th }}$ International Conference on the Ethiopian Economy, 710 June 2007. Addis Ababa, Ethiopia.

MataworkMilkias. 2016.Dairy production system, marketing and constraints in Ethiopia: Journal of Marketing and Consumer.29

MoFED; (Ministry of Finance and Economic Development).2015.Growth and Transformational Plan (GTP 20152020). Addis Ababa. Ethiopia.

Pauw, S. 2017. Agricultural Commercialization in Ethiopia: A Review of Warehouse Receipts in the Maize, Wheat, Sorghum and Tef Value Chains. USAID/Ethiopia Agriculture Knowledge, Learning, Documentation and Policy Project, Addis Abab.

Staal, S.J, Pratt A.N and Jabbar M. 2008.Dairy development for the resource poor. Part II: Kenya and Ethiopia dairy development case studies. PPLPI (Pro-poor Livestock Policy Initiative) Working Paper 44-2. ILRI (International Livestock Research Institute), Nairobi, Kenya.

Tshiunza, M., Lemchi, J.,andTenkouano, A., 2001. Determinants of Market Production of Cooking Banana in Nigeria. African Crop Science Journal 9 (3): 537-547.

WoldemichaelSomano, 2008. Dairy marketing chains analysis: The case of Shashemane, Hawassa and Dale districts milk shed, Southern Ethiopia. MSc thesis, School of Graduate Studies, Haramaya University, Ethiopia.

YacobAklilu and Catley Andy 2010.Mind the Gap: Commercialization, Livelihoods and Wealth Disparity in Pastoralist Areas of Ethiopia. Feinstein International Center, Tufts University, Addis Ababa.

Yamane, T. 1967. Statistics: An Introductory Analysis, $2^{\text {nd }}$ Edition.Harper\& Row, Publisher, New York. 919.

\section{Appendix Tables}

Appendix Table 1Conversion factor of Tropical Livestock Unit (TLU)

\begin{tabular}{llll}
\hline Livestock Category & TLU & Livestock Category & TLU \\
\hline Camel & 1.25 & Donkey (young) & 0.35 \\
Ox & 1.00 & Horse & 1.10 \\
Cow & 1.00 & Sheep (adult) & 0.13 Bull \\
& 0.34 & Sheep (young) & 0.06 \\
Heifer & 0.75 & Goat (adult) & 0.13 \\
Calf & 0.25 & Goat (young) & 0.06 \\
Donkey (adult) & 0.7 & Poultry & 0.013 \\
\hline
\end{tabular}

Source: Storck, et al., 1991

Appendix of the Table.2. Conversion factor used to compute man equivalent (Labour Force)

\begin{tabular}{lll}
\hline Age group & Male & Female \\
\hline$<10$ & 0.60 & 0.60 \\
$10-13$ & 0.90 & 0.70 \\
$14-16$ & 1.00 & 0.75 \\
$17-50$ & 1.00 & 0.75 \\
$>50$ & 1.00 & 0.75 \\
\hline
\end{tabular}

Source: Samuel and Sharp, 2008 